\title{
A Research on Multilayered Nonwovens as Orthopedic Support Structures for Medical Applications
}

\author{
Hatice Aktekeli Yilmaz \\ Graduate School of Natural and Applied Sciences, Department of Textile Engineering, \\ Ege University, 35100, Bornova, Izmir, Turkey \\ E-mail: htcaktekeli@gmail.com \\ Deniz Duran (Corresponding author) \\ Department of Textile Engineering, Faculty of Engineering, \\ Ege University, 35100, Bornova, Izmir, Turkey \\ E-mail: deniz.duran@ege.edu.tr
}

The research is financed by Ege University (BAP project 15-MÜH-049).

\begin{abstract}
During the last decades, nonwoven textiles have become widely used in the medical field due to their ease of use and due to the recent increase in the importance given to hygiene. In this study, multilayer nonwoven structures were developed in order to be used under the orthopedic bandages and plaster casts which are widely used in the fracture treatment. The aim of this development is to give more comfort and ease in use to the wearer. Wool, viscose and polypropylene were used as raw materials and multilayer nonwoven structures were produced by using meltblown and needling methods, then some samples were also combined with spunbond layers. Basis weight, thickness, air permeability, bending rigidity and water vapor permeability tests were applied to the multilayered nonwovens and the results were evaluated statistically by using SPSS software. The obtained results have shown that; two, three and multilayer nonwoven structures which can be used in the fracture treatment are good candidates to be replaced by cotton or synthetic pads since they provide better comfort to the user.
\end{abstract}

Keywords: Medical textiles, Medical nonwovens, Multilayer nonwovens, Meltblown, Needle punching

DOI: $10.7176 /$ JSTR/5-7-09

\section{Introduction}

Considering the advantages of disposable products for use and health, the use of these products in the medical sector is increasing day by day. Nonwoven products in the medical field include wound dressings, bandages, patches, gauze bandages, medical garments (gowns, caps, masks, uniforms, protective clothing), surgical coverings (covers, fabrics, curtains) bedspreads (blankets, sheets, pillow cases), urine holder pads (nappies/mattress pads), cloths, ladies sanitary pads, fabrics/cleaning cloths are used in a wide variety and comprehensive areas. This is because nonwoven products have the ease of production, suitability for use, price compatibility, barrier properties and increased efficiency (Rigby and Anand 2003). Today, hospitals are used in the treatment of fractures preferred cast-splints and pressure bandages, for filling purposes, in order to prevent the feeling of discomfort cotton pads or polyester, polypropylene fibers or synthetic and natural fibers obtained from different mixtures of rolls are used. These structures are applied just below the actual compression bandage or the cast-splint, and are expected to provide a buffering function to the body unit of interest, ensuring that the bandage/gum does not cut the skin and/or irritations, and that the pressure on the arm or leg in the banding is evenly distributed. Two or three layers can be used to achieve better cushioning in areas where the skin is indented or bones.

However, the properties of these structures are inadequate and can cause slippage problems during cast application so may cause burns and wounds, also may cause pressure wounds in patients because they do not have a uniform structure, because of sweating it may cause bad odor formation and irritation on 
the skin and may cause problems for health personnel (Sönmez 2007).

Domanski et al., 2003, with the foam material and spacer textile combination, developed a support structure with greater breathability than conventional supports, indicating that this structure reduces irritation or pressure sores (Domanski et al. 2003). Evans, 2008, developed a structure with an intermediate layer with two fabrics to be used under the cast layer. This structure is made of hydrophobic monofilament yarns to prevent moisture and bacteria formation due to long term use, to increase water resistance, breathability, resistance to impact and to provide lightness. In addition, the structure has the ability to stretch in the transverse and longitudinal direction so as to obtain the appropriate anatomic shape in the fracture area (Evans 2008). Kim et al., 2010, developed tubular support materials developed to prevent water-hardened plaster from damaging the skin. This tube structure, which consists of at least two layers of monofilaments, provides anti-bacterial and odor absorption properties and protects the skin under plaster. Thus, the feeling of discomfort, itching and sweat caused by the use of cotton is prevented (Kim, Youn and Choi 2010). Evans, 2012, knitted sandwich structure using hydrophobic monofilament yarns have developed as breathable orthopedic support material. This structure, which protects the skin, prevents the formation of pressure wounds, odor formation, the wetness and discomfort caused by perspiration, has been stated that the comfort of the patients during the treatment and the sandwich structure gives a feeling of safety thanks to the sandwich structure (Evans 2012).

Since foam and spacer structures are used in the studies in the literature, their properties have not reached the structure used today and have not found widespread use.

In this study, two, three or multi-layer nonwoven structures were designed and developed to replace cotton and synthetic pads under cast and orthopedic bandages for patients. Polypropylene, viscose and wool were used as raw material, and multi-layer surfaces were produced to provide sufficient thickness and performance characteristics. In addition, spunbond surface was used as an additional layer in some structures. In the scope of this research, the production methods of the samples, the raw materials used and the test methods applied to these samples were examined in detail and as a result of the data obtained from the test results, it was concluded that these structures were suitable for use under cast and orthopedic bandages by eliminating the negative effects of cotton pads and synthetic rolls.

\section{Materials and Methods}

Meltblown and needling surfaces were produced and spunbond surface was supplied as ready. Surface bonding was again performed by needling method. During the production of needle punched surfaces, wool fibers were used due to the fact that it allows the passage of air and humidity in both directions, creating a natural microclimate effect, absorbing more than $30 \%$ of the moisture vapor without giving a feeling of wetness and removing odors due to its structure; viscose fibers have been used due to its high water/sweat absorption ability, elasticity and smooth surface and smooth structure.

In the meltblown method, polypropylene granules, one of the most important and most used raw materials of this method, have been used at a flow rate of 1100 MFR. The most common and current definition used for the meltblown method is the one-step process, where the thermoplastic raw material is melted in the extruder and is sprayed by high speed airflow and the surface which has self bonded microfibers, occur onto the cylinder (Duran 2004).

In the meltblown process; air temperature, die temperature, die to distance collector drum speed (DCD), speed of the collector drum, amount of polymer and air volume are machine parameters that can be changed. In this study 3 different basis weights were obtained by changing the speed of the collector drum.

In table 1, the process parameters of the meltblown process are given: All process parameters of needling process are given in table 2 .

Meltblown-Needling, Meltblown-Needling-Spunbond, Meltblown-Needling-Meltblown and Meltblown, needling, spunbond surfaces using together two, three and multi-layer sandwich structures were produced.

M1, M2, M3 represent respectively high, medium and low weight meltblown, $\mathrm{N}$ w1 low weight wool, $\mathrm{N}$ w2 high weight wool, N v1 low weight viscose, N v2 high weight viscose and S spunbond. Group A samples are considered to be equivalent to the tube knitting structure called stockinette used under American casts, $\mathrm{B}$ and $\mathrm{C}$ group structures are considered as equivalent to the cotton for used under cast. All combinations are given in table 3.

The air permeability, thickness, basis weight, bending strength and water vapor permeability tests of the samples were measured.

Tests and standards are given in table 4. 
International Journal of Scientific and Technological Research

ISSN 2422-8702 (Online), DOI: 10.7176/JSTR/5-7-09

Vol.5, No.7, 2019

Table 1. Process Parameters of Meltblown Process

\begin{tabular}{|l|c|c|c|}
\hline \multicolumn{1}{|c|}{ Process Parameters } & M1 & M2 & M3 \\
\hline Air temperature $\left({ }^{\circ} \mathrm{F}\right)$ & 390 & 390 & 390 \\
\hline Air high limit temperature $\left({ }^{\circ} \mathrm{F}\right)$ & 475 & 475 & 475 \\
\hline Extruder temperature Zone $3\left({ }^{\circ} \mathrm{F}\right)$ & 390 & 390 & 390 \\
\hline Extruder temperature Zone $2\left({ }^{\circ} \mathrm{F}\right)$ & 340 & 340 & 340 \\
\hline Extruder temperature Zone $1\left({ }^{\circ} \mathrm{F}\right)$ & 290 & 290 & 290 \\
\hline Die metal temperature $\left({ }^{\circ} \mathrm{F}\right)$ & 370 & 370 & 370 \\
\hline Extruder speed $(\%)$ & 20 & 20 & 20 \\
\hline Melt flow rate $(\mathrm{Psi})$ & 360 & 360 & 360 \\
\hline DCD $(\mathrm{cm})$ & 100 & 100 & 100 \\
\hline Collector drum speed $(\mathrm{ft} / \mathrm{min})$ & 20 & 40 & 60 \\
\hline Basis weight $\left(\mathrm{g} / \mathrm{m}^{2}\right)$ & 95 & 54 & 38 \\
\hline
\end{tabular}

Table 2. Process Parameters for Needling Method

\begin{tabular}{|l|c|c|c|c|}
\hline \multicolumn{1}{|c|}{ Process Parameters } & $\mathbf{N}_{\mathbf{1} 1}$ & $\mathbf{N}_{\mathbf{2} 2}$ & $\mathbf{N}_{\mathbf{1} 1}$ & $\mathbf{N}_{\mathbf{2} 2}$ \\
\hline Feeding speed $(\mathrm{m} / \mathrm{min})$ & 5 & 3 & 5 & 3 \\
\hline Penetration depth $(\mathrm{mm})$ & 10 & 5 & 10 & 7 \\
\hline Basis weight $\left(\mathrm{g} / \mathrm{m}^{2}\right)$ & 119,0 & 191,2 & 121,0 & 175,8 \\
\hline
\end{tabular}

Table 3.Surface Combinations

\begin{tabular}{|c|c|c|c|c|c|}
\hline $\begin{array}{l}\text { Sample } \\
\text { Name } \\
\end{array}$ & & $\begin{array}{l}\text { Sample } \\
\text { Name }\end{array}$ & & $\begin{array}{l}\text { Sample } \\
\text { Name } \\
\end{array}$ & \\
\hline A1 & $\mathrm{M} 1+\mathrm{N}_{\mathrm{W} 1}$ & $\mathrm{~B} 1$ & $\mathrm{M} 1+\mathrm{N}_{\mathrm{W} 1}+\mathrm{S}$ & $\mathrm{C} 1$ & $\mathrm{M} 1+\mathrm{N}_{\mathrm{W} 1}+\mathrm{M} 3$ \\
\hline $\mathrm{A} 2$ & $\mathrm{M} 2+\mathrm{N}_{\mathrm{W} 1}$ & $\mathrm{~B} 2$ & $\mathrm{M} 2+\mathrm{N}_{\mathrm{W} 1}+\mathrm{S}$ & $\mathrm{C} 2$ & $\mathrm{M} 2+\mathrm{N}_{\mathrm{W} 1}+\mathrm{M} 3$ \\
\hline $\mathrm{A} 3$ & $\mathrm{M} 3+\mathrm{N}_{\mathrm{W} 1}$ & B3 & $\mathrm{M} 3+\mathrm{N}_{\mathrm{W} 1}+\mathrm{S}$ & $\mathrm{C} 3$ & $\mathrm{M} 3+\mathrm{N}_{\mathrm{W} 1}+\mathrm{M} 3$ \\
\hline A4 & $\mathrm{M} 1+\mathrm{N}_{\mathrm{W} 2}$ & B4 & $\mathrm{M} 1+\mathrm{N}_{\mathrm{W} 2}+\mathrm{S}$ & $\mathrm{C} 4$ & $\mathrm{M} 1+\mathrm{N}_{\mathrm{W} 2}+\mathrm{M} 3$ \\
\hline A5 & $\mathrm{M} 2+\mathrm{N}_{\mathrm{W} 2}$ & B5 & $\mathrm{M} 2+\mathrm{N}_{\mathrm{W} 2}+\mathrm{S}$ & $\mathrm{C} 5$ & $\mathrm{M} 2+\mathrm{N}_{\mathrm{W} 2}+\mathrm{M} 3$ \\
\hline A6 & $\mathrm{M} 3+\mathrm{N}_{\mathrm{W} 2}$ & B6 & $\mathrm{M} 3+\mathrm{N}_{\mathrm{W} 2}+\mathrm{S}$ & $\mathrm{C} 6$ & $\mathrm{M} 3+\mathrm{N}_{\mathrm{W} 2}+\mathrm{M} 3$ \\
\hline A7 & $\mathrm{M} 1+\mathrm{N}_{\mathrm{V} 1}$ & B7 & $\mathrm{M} 1+\mathrm{N}_{\mathrm{V} 1}+\mathrm{S}$ & $\mathrm{C} 7$ & $\mathrm{M} 1+\mathrm{N}_{\mathrm{V} 1}+\mathrm{M} 3$ \\
\hline A8 & $\mathrm{M} 2+\mathrm{N}_{\mathrm{V} 1}$ & $\mathrm{~B} 8$ & $\mathrm{M} 2+\mathrm{N}_{\mathrm{V} 1}+\mathrm{S}$ & $\mathrm{C} 8$ & $\mathrm{M} 2+\mathrm{N}_{\mathrm{V} 1}+\mathrm{M} 3$ \\
\hline A9 & $\mathrm{M} 3+\mathrm{N}_{\mathrm{V} 1}$ & B9 & $\mathrm{M} 3+\mathrm{N}_{\mathrm{V} 1}+\mathrm{S}$ & C9 & $\mathrm{M} 3+\mathrm{N}_{\mathrm{V} 1}+\mathrm{M} 3$ \\
\hline A10 & $\mathrm{M} 1+\mathrm{N}_{\mathrm{V} 2}$ & $\mathrm{~B} 10$ & $\mathrm{M} 1+\mathrm{N}_{\mathrm{V} 2}+\mathrm{S}$ & $\mathrm{C} 10$ & $\mathrm{M} 1+\mathrm{N}_{\mathrm{V} 2}+\mathrm{M} 3$ \\
\hline A11 & $\mathrm{M} 2+\mathrm{N}_{\mathrm{V} 2}$ & B11 & $\mathrm{M} 2+\mathrm{N}_{\mathrm{V} 2}+\mathrm{S}$ & $\mathrm{C} 11$ & $\mathrm{M} 2+\mathrm{N}_{\mathrm{V} 2}+\mathrm{M} 3$ \\
\hline A12 & $\mathrm{M} 3+\mathrm{N}_{\mathrm{V} 2}$ & $\mathrm{~B} 12$ & $\mathrm{M} 3+\mathrm{N}_{\mathrm{V} 2}+\mathrm{S}$ & $\mathrm{C} 12$ & $\mathrm{M} 3+\mathrm{N}_{\mathrm{V} 2}+\mathrm{M} 3$ \\
\hline A13 & $\mathrm{M} 1+\mathrm{N}_{\mathrm{V} 1}+\mathrm{N}_{\mathrm{W} 1}$ & $\mathrm{~B} 13$ & $\mathrm{M} 1+\mathrm{N}_{\mathrm{V} 1}+\mathrm{N}_{\mathrm{W} 1}+\mathrm{S}$ & $\mathrm{C} 13$ & $\mathrm{M} 1+\mathrm{N}_{\mathrm{V} 1}+\mathrm{N}_{\mathrm{W} 1}+\mathrm{M} 3$ \\
\hline A14 & $\mathrm{M} 2+\mathrm{N}_{\mathrm{V} 1}+\mathrm{N}_{\mathrm{W} 1}$ & $\mathrm{~B} 14$ & $\mathrm{M} 2+\mathrm{N}_{\mathrm{V} 1}+\mathrm{N}_{\mathrm{W} 1}+\mathrm{S}$ & $\mathrm{C} 14$ & $\mathrm{M} 2+\mathrm{N}_{\mathrm{V} 1}+\mathrm{N}_{\mathrm{W} 1}+\mathrm{M} 3$ \\
\hline A15 & $\mathrm{M} 3+\mathrm{N}_{\mathrm{V} 1}+\mathrm{N}_{\mathrm{W} 1}$ & $\mathrm{~B} 15$ & $\mathrm{M} 3+\mathrm{N}_{\mathrm{V} 1}+\mathrm{N}_{\mathrm{W} 1}+\mathrm{S}$ & $\mathrm{C} 15$ & $\mathrm{M} 3+\mathrm{N}_{\mathrm{V} 1}+\mathrm{N}_{\mathrm{W} 1}+\mathrm{M} 3$ \\
\hline A16 & $\mathrm{M} 1+\mathrm{N}_{\mathrm{V} 1}+\mathrm{S}+\mathrm{N}_{\mathrm{W} 1}$ & $\mathrm{~B} 16$ & $\mathrm{M} 1+\mathrm{N}_{\mathrm{V} 1}+\mathrm{S}+\mathrm{N}_{\mathrm{W} 1}+\mathrm{S}$ & $\mathrm{C} 16$ & $\mathrm{M} 1+\mathrm{N}_{\mathrm{V} 1}+\mathrm{S}+\mathrm{N}_{\mathrm{W} 1}+\mathrm{M} 3$ \\
\hline A17 & $\mathrm{M} 2+\mathrm{N}_{\mathrm{V} 1}+\mathrm{S}+\mathrm{N}_{\mathrm{W} 1}$ & $\mathrm{~B} 17$ & $\mathrm{M} 2+\mathrm{N}_{\mathrm{V} 1}+\mathrm{S}+\mathrm{N}_{\mathrm{W} 1}+\mathrm{S}$ & $\mathrm{C} 17$ & $\mathrm{M} 2+\mathrm{N}_{\mathrm{V} 1}+\mathrm{S}+\mathrm{N}_{\mathrm{W} 1}+\mathrm{M} 3$ \\
\hline A18 & $\mathrm{M} 3+\mathrm{N}_{\mathrm{V} 1}+\mathrm{S}+\mathrm{N}_{\mathrm{W} 1}$ & B18 & $\mathrm{M} 3+\mathrm{N}_{\mathrm{V} 1}+\mathrm{S}+\mathrm{N}_{\mathrm{W} 1}+\mathrm{S}$ & C18 & $\mathrm{M} 3+\mathrm{N}_{\mathrm{V} 1}+\mathrm{S}+\mathrm{N}_{\mathrm{W} 1}+\mathrm{M} 3$ \\
\hline
\end{tabular}


Table 4. Tests and Standards

\begin{tabular}{|l|l|}
\hline TEST & STANDARD \\
\hline Air Permeability & TS 391 EN ISO 9237 \\
\hline Bending Strength & ASTM D4032 \\
\hline Thickness & TS 7128 EN ISO 5084 \\
\hline Basis Weight & TS EN ISO 29073-1 \\
\hline Water Vapor Permeability & BS 7209:1990 \\
\hline
\end{tabular}

\section{Results and Discussion}

Air permeability, thickness, basis weight, bending strength and water vapor permeability tests were performed to the samples and the results were statistically evaluated by using SPSS software.

\subsection{Results of Thickness Test}

Thickness measurement of the samples was measured according to TS 7128 EN ISO 5084 standard with the Thickness Gauge M034A thickness device.

The thickness values of the two, three or multi-layer structures formed by meltblown, needling and spunbond surfaces were examined with 3 different combinations for each graph. The measurement results of the combinations of group A surfaces are given in figure 1.

The thickness results of the group B samples are given in figure 2.

The thickness results of the group $\mathrm{C}$ samples are given in figure 3 .

When the thickness results of the samples are examined, it is clearly seen that the difference between the results is mainly affected by the surfaces produced by the needling method. The spunbond and meltblown surfaces used as additional layers were very thin and not voluminous and the thickness measurements in the A, B and C groups showed close values for this reason. The lowest results were obtained with the samples with low weight wool and low weight viscose on separate surfaces, while the highest results were obtained on the surfaces with low weight wool and low weight viscose. As the number of layers used in the samples increased, the thickness value increased. Even though the lowest thickness value were expected to be obtained from sample $\mathrm{C} 15$, the lowest value was given by sample $\mathrm{C} 14$. It is thought that this result is due to a lack of homogeneity in the needling layer.

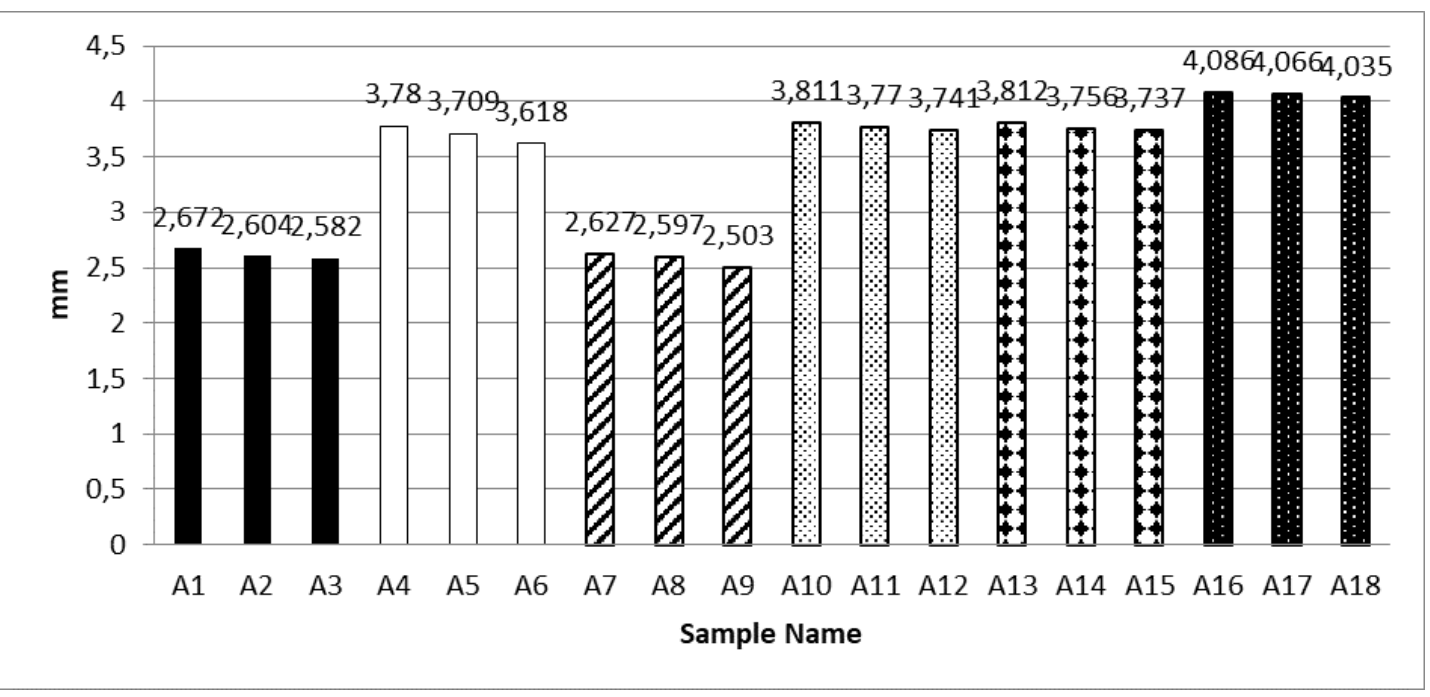

Figure 1. Thickness Measurement Results of Group A Samples 


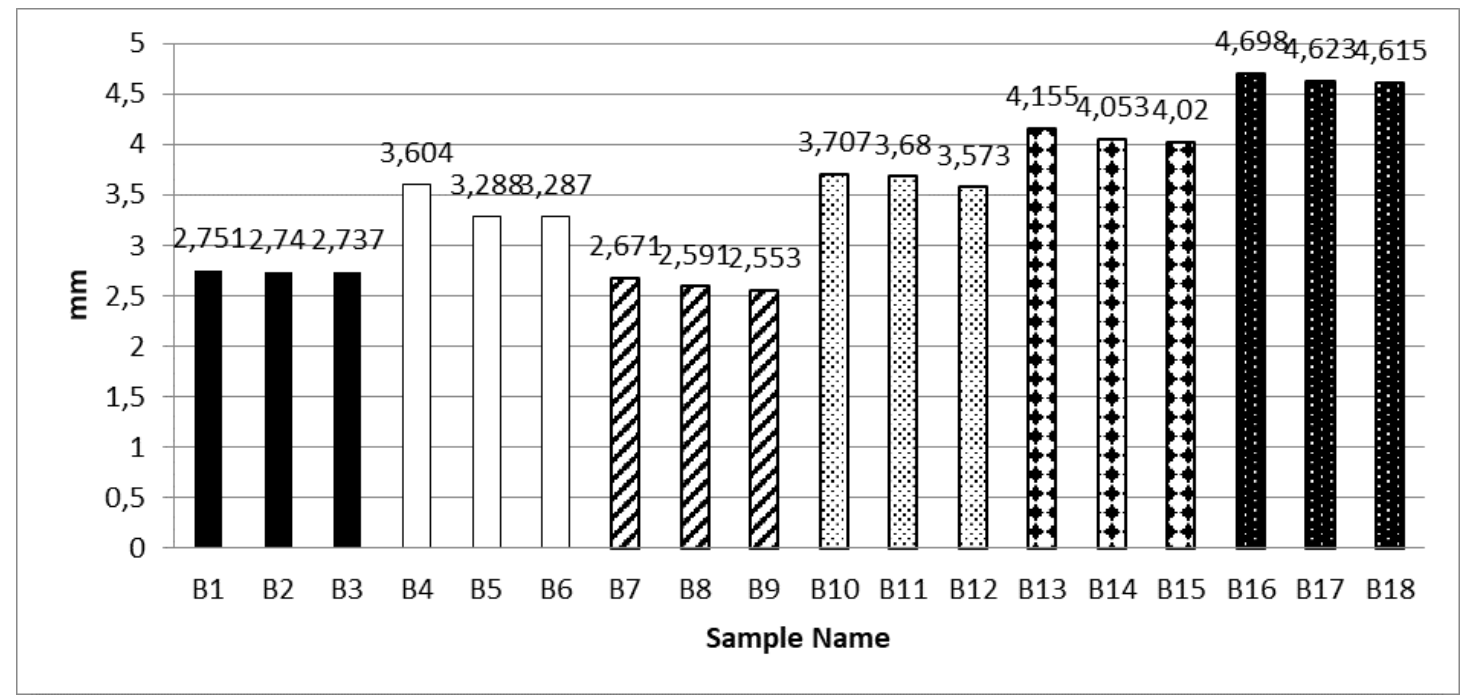

Figure 2. Thickness Measurement Results of Group B Samples

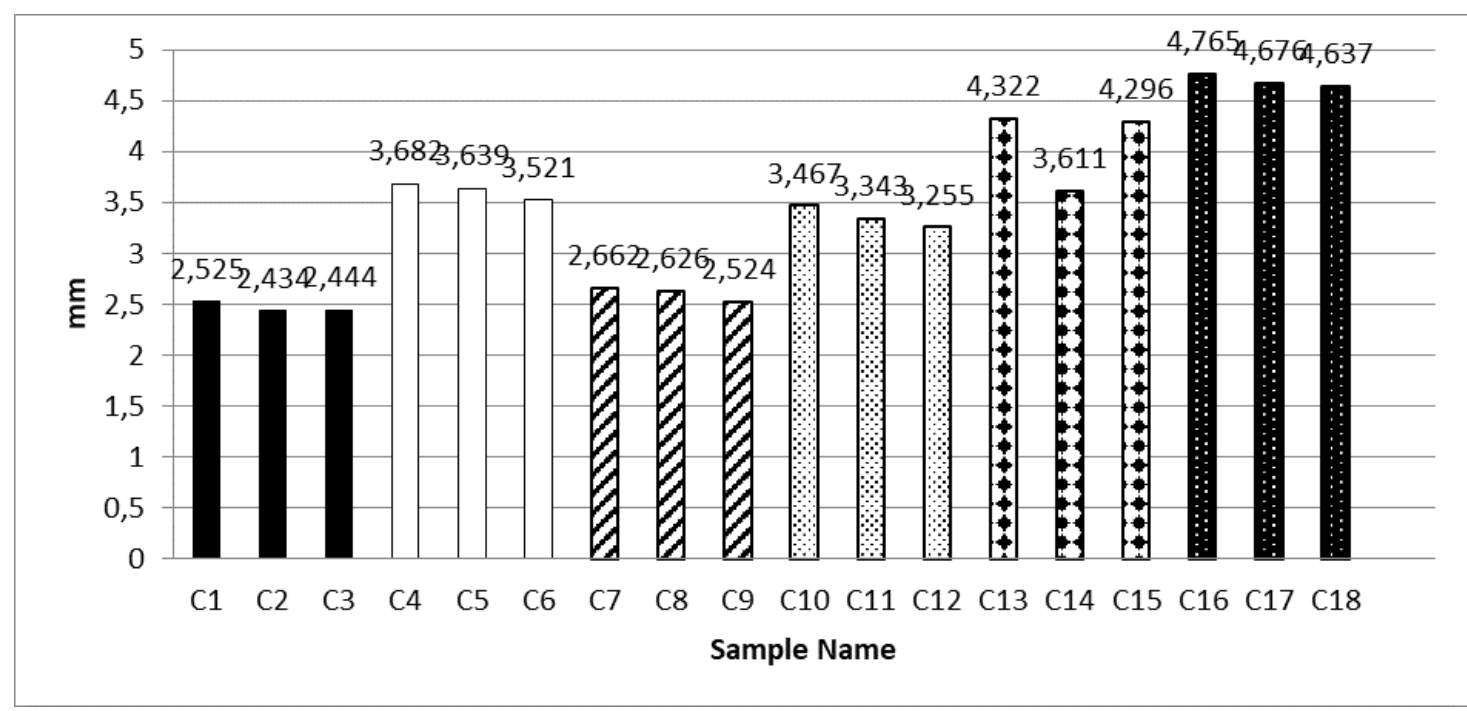

Figure 3. Thickness Measurement Results of Group C Samples

\subsection{Results of Basis Weight Test}

The test standard of the grammage measurement is TS EN ISO 29073-1. The basis weight values of two, three or multi-layer structures formed by meltblown, needling and spunbond surfaces were investigated with 3 different combinations for each graph.

The measurement results of the combinations of group A surfaces are given in figure 4 .

The basis weight results of the group B samples are given in figure 5 .

The basis weight results of the group $\mathrm{C}$ samples are given in figure 6.

The lowest results were obtained in samples with low weight wool and low weight viscose on separate surfaces, while the highest results were obtained on the surfaces with low weight and low weight viscose. As the number of layers used in the samples increased, the weight value increased. Lowest basis weight values of group $\mathrm{C}$ samples were obtained from sample $\mathrm{C} 14$, following the same trend as the thickness test results. 
International Journal of Scientific and Technological Research

ISSN 2422-8702 (Online), DOI: 10.7176/JSTR/5-7-09

www.iiste.org

Vol.5, No.7, 2019

IISTE

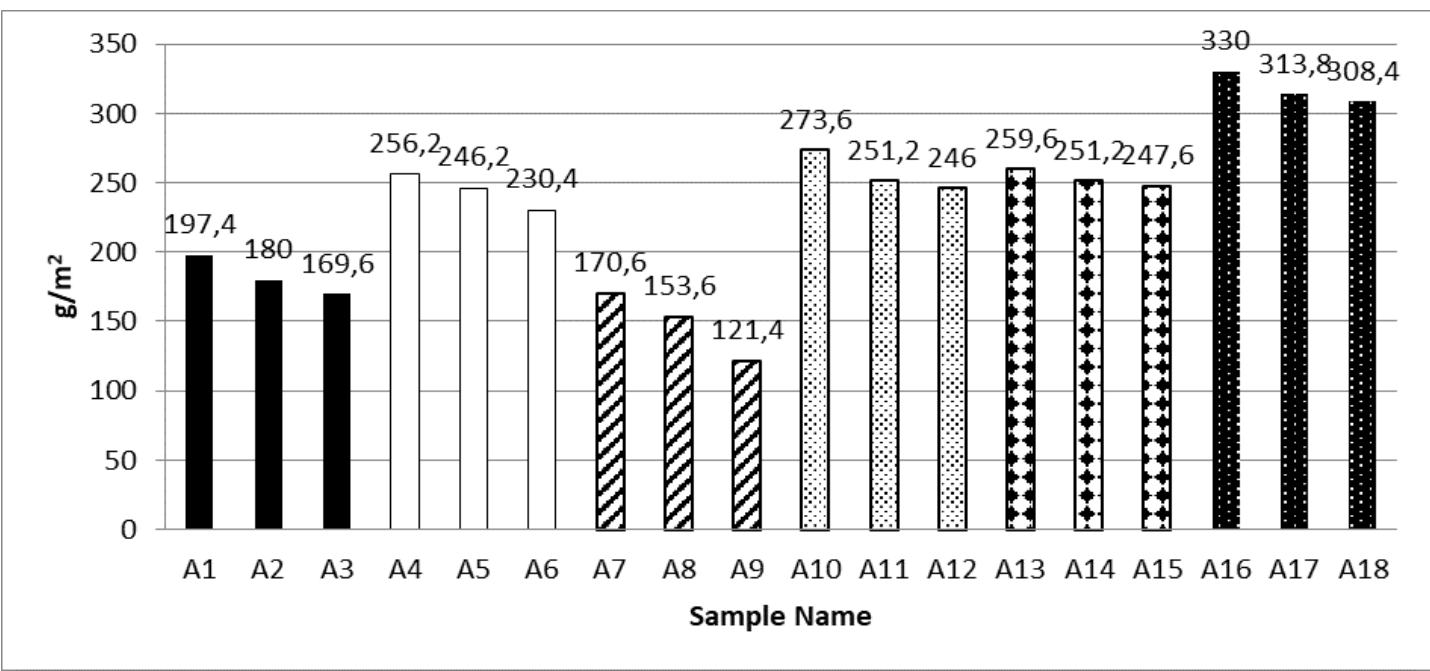

Figure 4.Basis Weight Measurements of Group A Samples

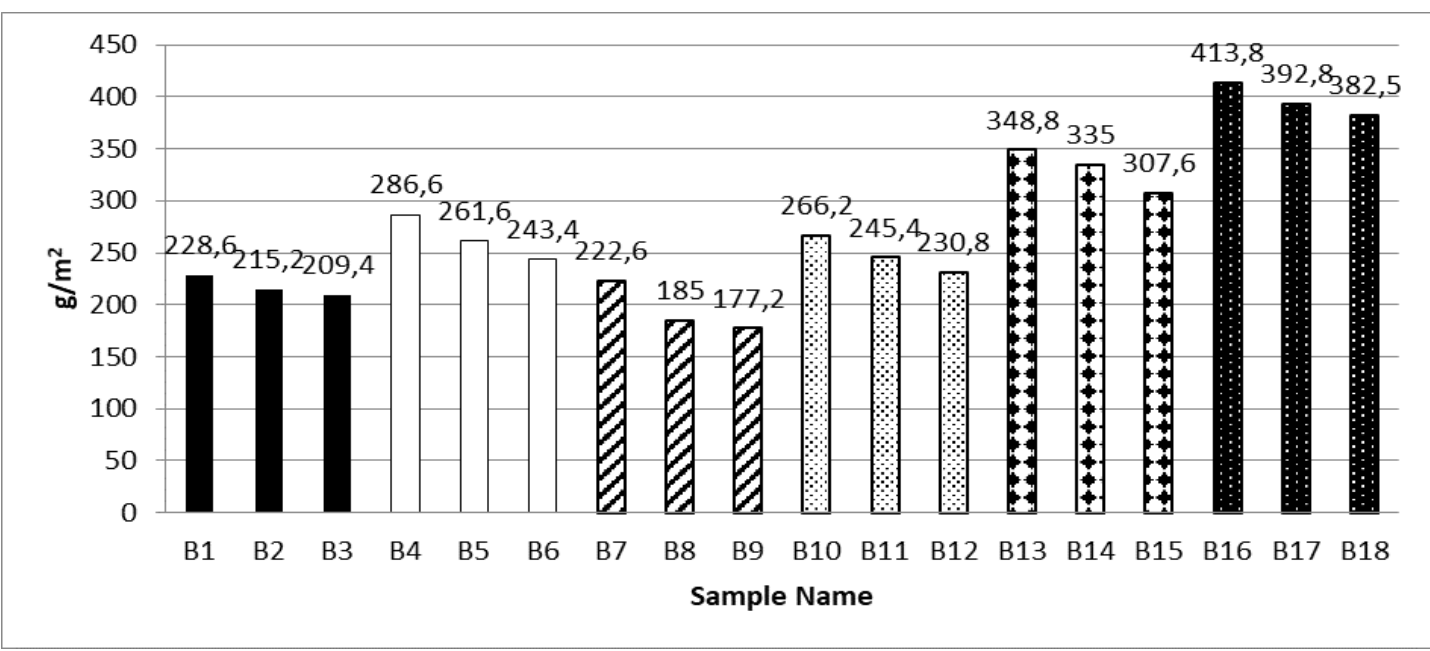

Figure 5.Basis Weight Measurements of Group B Samples

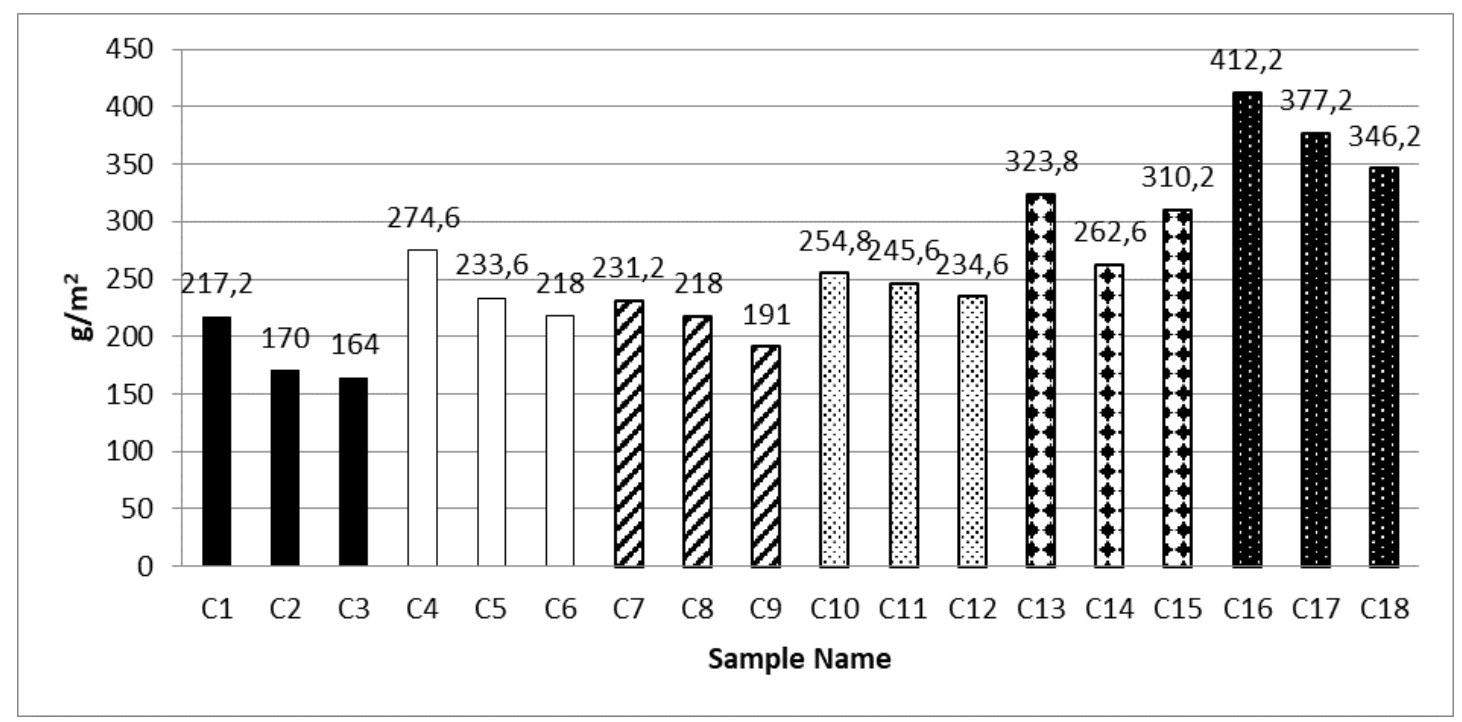

Figure 6.Basis Weight Measurements of Group C Samples 


\subsection{Results of Air Permeability Test}

Air permeability of the samples was made according to TS 391 EN ISO 9237 standard by FX 3300 digital air permeability tester. Air permeability values of two, three or multi-layer structures formed by meltblown, needling and spunbond surfaces were examined with 3 different combinations for each graph. The measurement results of the combinations of group A surfaces are given in figure 7.

The air permeability results of the group B samples are given in figure 8 .

The air permeability results of the group $\mathrm{C}$ samples are given in figure 9.

When the air permeability measurement results of all combinations are examined; it can be seen that combinations with meltblown M1 surface gave the lowest values. This is due to the fact that basis weight of M1 is $95 \mathrm{~g} / \mathrm{m} 2$ and has the highest thickness, the most heavy and voluminous meltblown surface, and the air permeability of the M1 surface is lower than the M2 and M3 surfaces. In combination with the M2 and M3 surfaces, values increase in order. The combinations with 54g/m 2 weighted M2 surface gave higher values, and combinations with $38 \mathrm{~g} / \mathrm{m} 2$ weighted M3 surface gave the highest values.

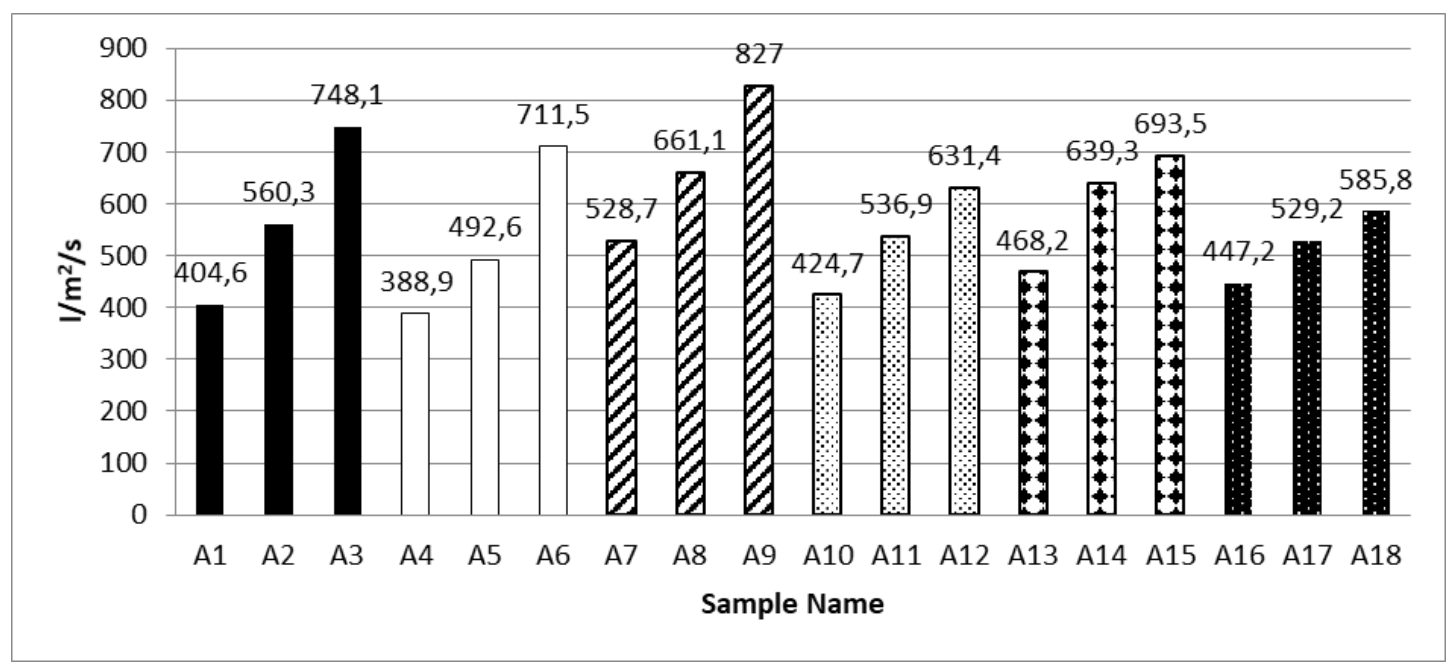

Figure 7. Air Permeability Measurement Results of Group A Samples

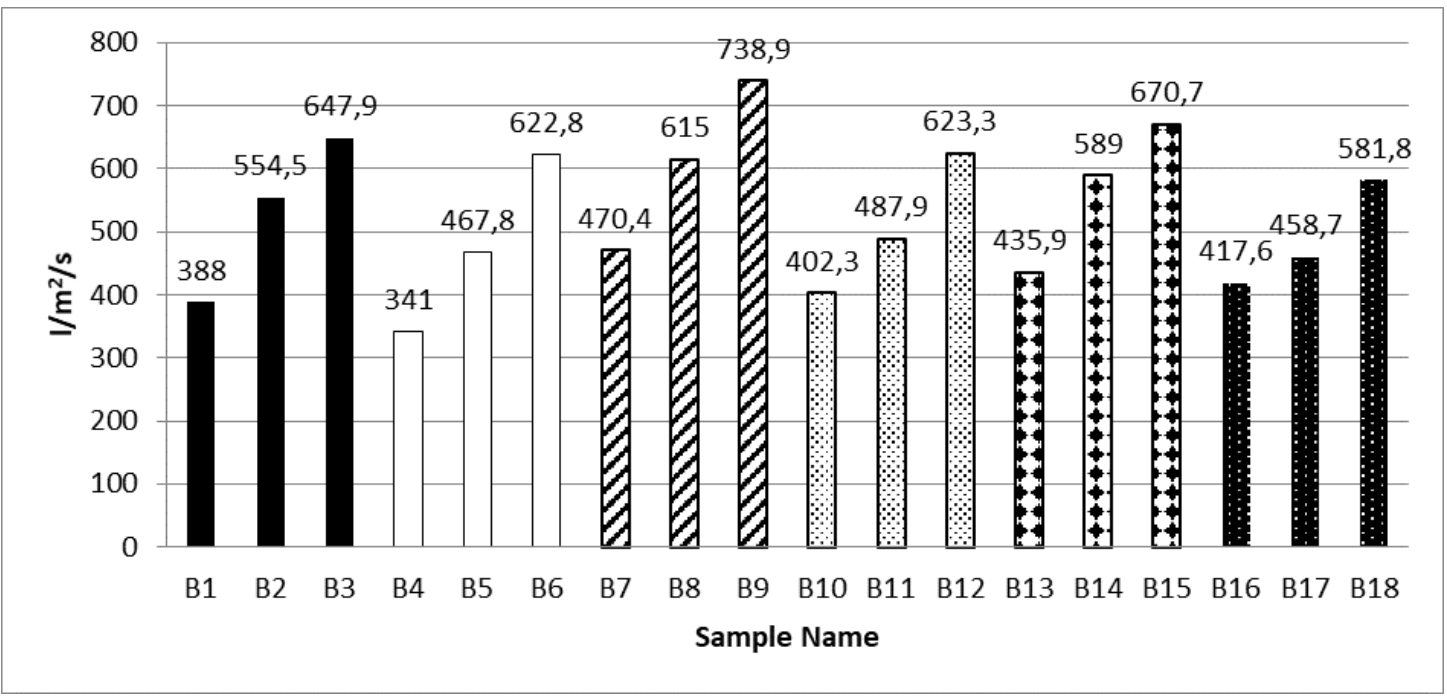

Figure 8. Air Permeability Measurement Results of Group B Samples 


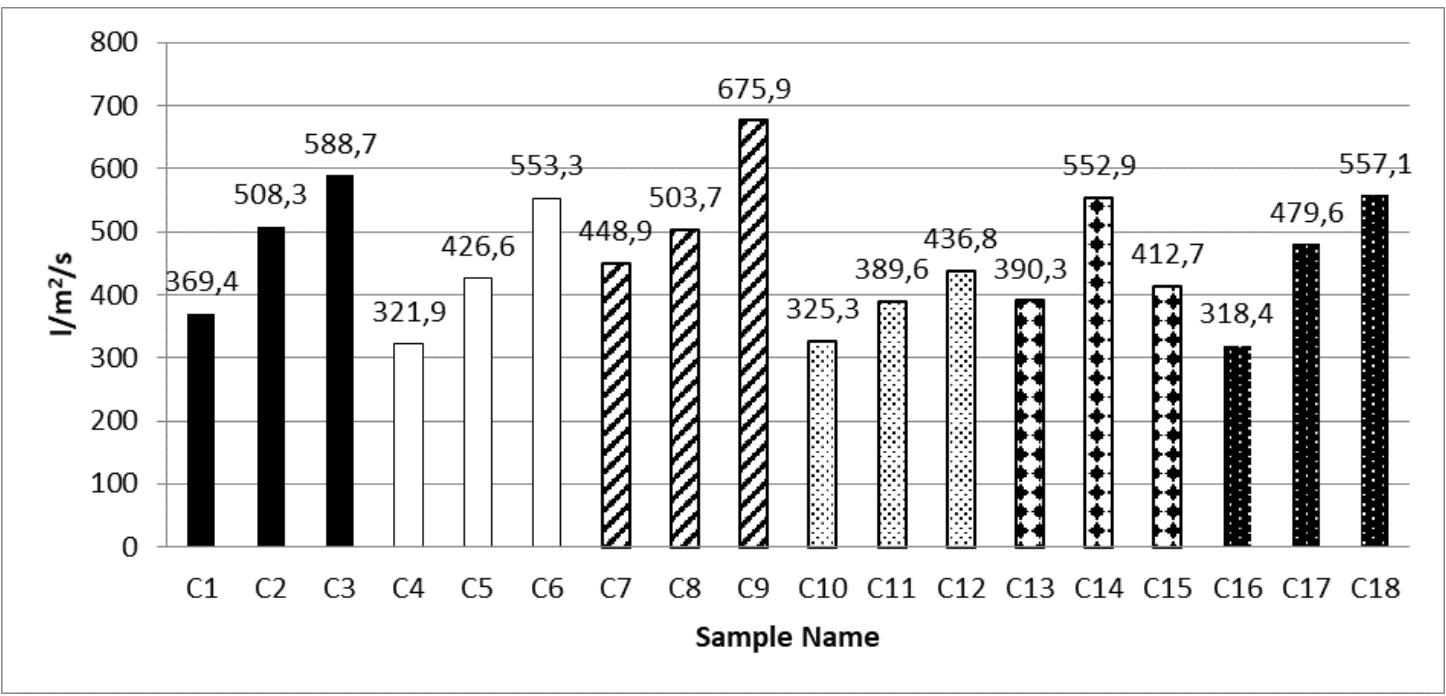

Figure 9. Air Permeability Measurement Results of Group C Samples

It was observed that the results of group B was lower than the results of group A samples. This difference is due to the spunbond surface, the third layer being used. The results of the measurement of the $\mathrm{C}$ group samples were lower than the B group samples. This difference is due to the fact that the meltblown surface used as the final layer has a more closed, in other words less porous structure than the spunbond surface. Using the SPSS software, the basis weight, thickness and air permeability of the meltblown surface were found to have a statistically significant affect on the air permeability of the sample according to the results evaluated with the analysis of variance in the $95 \%$ confidence interval.

Results of variance analysis on air permeability of meltblown surfaces are given table 5.

As the basis weight and thickness of the meltblown surface decreased, the air permeability values of the samples increased in all combinations as the air permeability increased.

According to the results evaluated by variance analysis using SPSS software, the basis weight, and air permeability values of the needle viscose, wool surfaces and spunbond surface used in the A and B group samples were not statistically significant for the air permeability results (according to $\alpha=0.05$ ). For the air permeability results of the $\mathrm{C}$ group samples, it was not found statistically significant that the basis weight, thickness and air permeability values of the needled wool surfaces and whether or not use of spunbond surfaces, however, the weight, thickness and air permeability values of the needling viscose surfaces were found to be statistically significant (according to $\alpha=0.05$ ). Air permeability values decreased with increasing basis weight and thickness of viscose surfaces and decreasing air permeability of viscose surfaces.

Significance values are given in table 6 .

Table 5. Results of Variance Analysis on Air Permeability of Meltblown Surfaces

\begin{tabular}{|l|l|l|l|}
\hline Parameters & $\begin{array}{l}\text { Meltblown basis } \\
\text { weight }\end{array}$ & $\begin{array}{l}\text { Meltblown } \\
\text { thickness }\end{array}$ & $\begin{array}{l}\text { Meltblown air } \\
\text { permeability }\end{array}$ \\
\cline { 2 - 4 } & Significance & Significance & Significance \\
\hline Group A &, 000 &, 000 &, 000 \\
\hline Group B &, 000 &, 000 &, 000 \\
\hline Group C &, 000 &, 000 &, 000 \\
\hline
\end{tabular}


Table 6. Results of Variance Analysis on Air Permeability of Needling Surface and Spunbond Surface

\begin{tabular}{|l|l|l|l|}
\hline Parameters & Group A & Group B & Group C \\
\hline & Significance & Significance & Significance \\
\hline Needling wool basis weight &, 193 &, 091 &, 645 \\
\hline Needling wool thickness &, 349 &, 166 &, 831 \\
\hline Needling wool air permeability &, 193 &, 091 &, 645 \\
\hline Needling viscose basis weight &, 111 &, 133 &, 004 \\
\hline Needling viscose thickness &, 218 &, 245 &, 012 \\
\hline Needling viscose air permeability &, 111 &, 133 &, 004 \\
\hline Spunbond basis weight & - &, 116 &, 697 \\
\hline Spunbond thickness & - &, 116 &, 697 \\
\hline Spunbond air permeability & - &, 116 &, 697 \\
\hline
\end{tabular}

\subsection{Results of Bending Strength Test}

The bending strength of the samples was made according to the ASTM D 4032 standard with SDL Atlas circular bending strength tester. The bending strength values of the two, three and multi-layer structures formed by meltblown, needling and spunbond surfaces were examined with 3 different combinations for each graph.

The measurement results of group A combinations are given in figure 10 .

When the bending strength results of the A group samples were examined, it was observed that the bending strength values of the combinations with low basis weight wool (Nw1) and low basis weight viscose (Nv1) were given the lowest values while the values of the samples increased as the thickness and layers increased. According to the results evaluated by variance analysis using SPSS software in group A combinations, the thickness and basis weight of needling wool, viscose and the thickness and basis weight of meltblown surface for the bending strength were found to be significant according to the significance coefficient $\alpha=0.05$. The results are given table 7. As the thickness and basis weight of the meltblown and needle surfaces used in the samples increased, the bending strength results increased.

When the subgroups were examined, the meltblown weight increased from $38 \mathrm{~g} / \mathrm{m} 2$ to $54 \mathrm{~g} / \mathrm{m} 2$ thickness from $0.6 \mathrm{~mm}$ to $0.75 \mathrm{~mm}$, were not found to be statistically significant; the increase in basis weight to 95 $\mathrm{g} / \mathrm{m} 2$ and the thickness to $1.24 \mathrm{~mm}$ were found to be statistically significant for bending strength values. As the basis weight and thickness of the wool and viscose surface increased, the bending strength values increased.

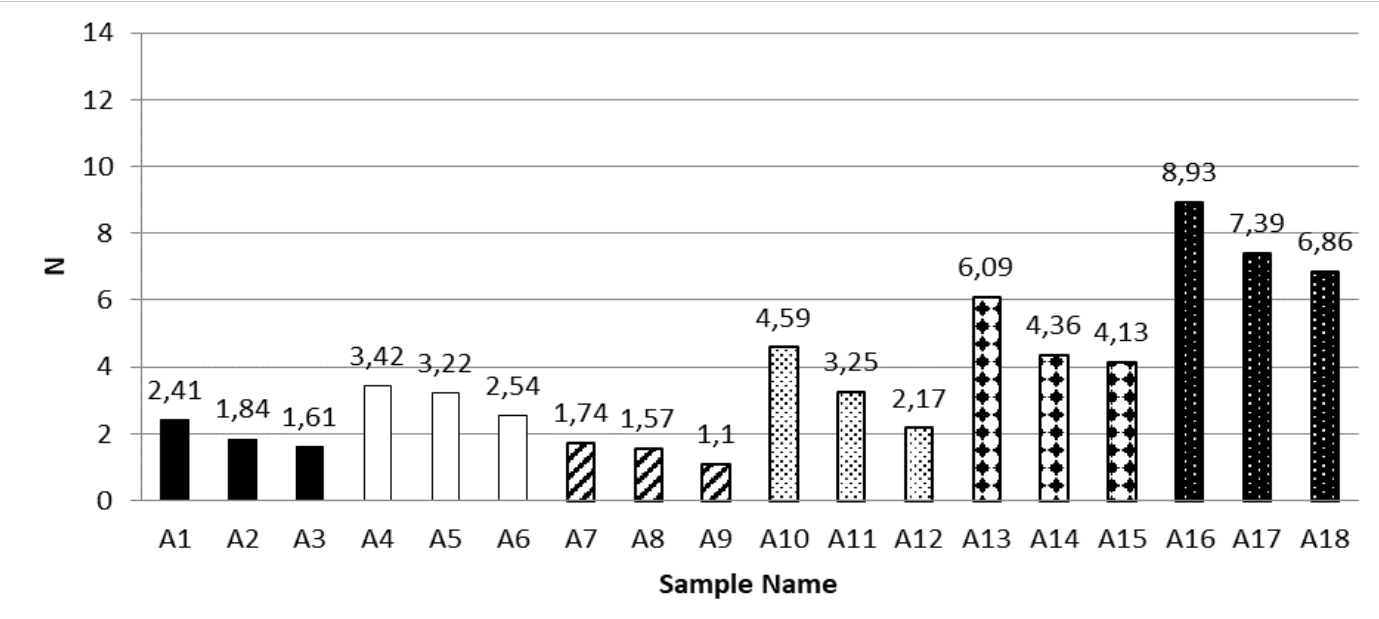

Figure 10. Bending Strength Measurement Results of Group A Samples 
Table 7. The Results of Variance Analysis on the Bending Strength of Needling and Meltblown Surfaces in Group A Samples

\begin{tabular}{|l|l|}
\hline Parameters & Significance \\
\hline Needling wool basis weight &, 000 \\
\hline Needling wool thickness &, 000 \\
\hline Needling viscose basis weight &, 000 \\
\hline Needling viscose thickness &, 000 \\
\hline Meltblown basis weight &, 035 \\
\hline Meltblown thickness &, 035 \\
\hline
\end{tabular}

The measurement results of group B combinations are given in figure 11 .

When the results of bending strength of B group samples are examined; higher results were obtained than the A group results. This is because the spunbond surface is used as an additional layer. The spunbond structure increased the hardness of the samples slightly compared to the A group combinations, resulting in higher bending strength results. When the samples were evaluated among themselves, the highest values were obtained in the samples consisting of meltblown-low weight viscose-spunbond-low weight wool-spunbond surfaces with the highest layer. The lowest values are given by the combination of low weight wool and low weight viscose.

According to the results evaluated by variance analysis using SPSS software in B group combinations, the basis weight and thickness of wool and viscose surfaces, meltblown and spunbond surfaces were found to be significant according to $\alpha=0.05$ significance coefficient.

The results are given table 8 .

When the subgroups were examined, the meltblown weight increased from $38 \mathrm{~g} / \mathrm{m} 2$ to $54 \mathrm{~g} / \mathrm{m} 2$ thickness from $0.6 \mathrm{~mm}$ to $0.75 \mathrm{~mm}$ were not found statistically significant; whereas the meltblown weight increased from $38 \mathrm{~g} / \mathrm{m} 2$ to $95 \mathrm{~g} / \mathrm{m} 2$ thickness from $0.6 \mathrm{~mm}$ to $1.24 \mathrm{~mm}$ were found to be statistically significant for bending strength values. As the weight of the wool and viscose surface increased, the bending strength values increased.

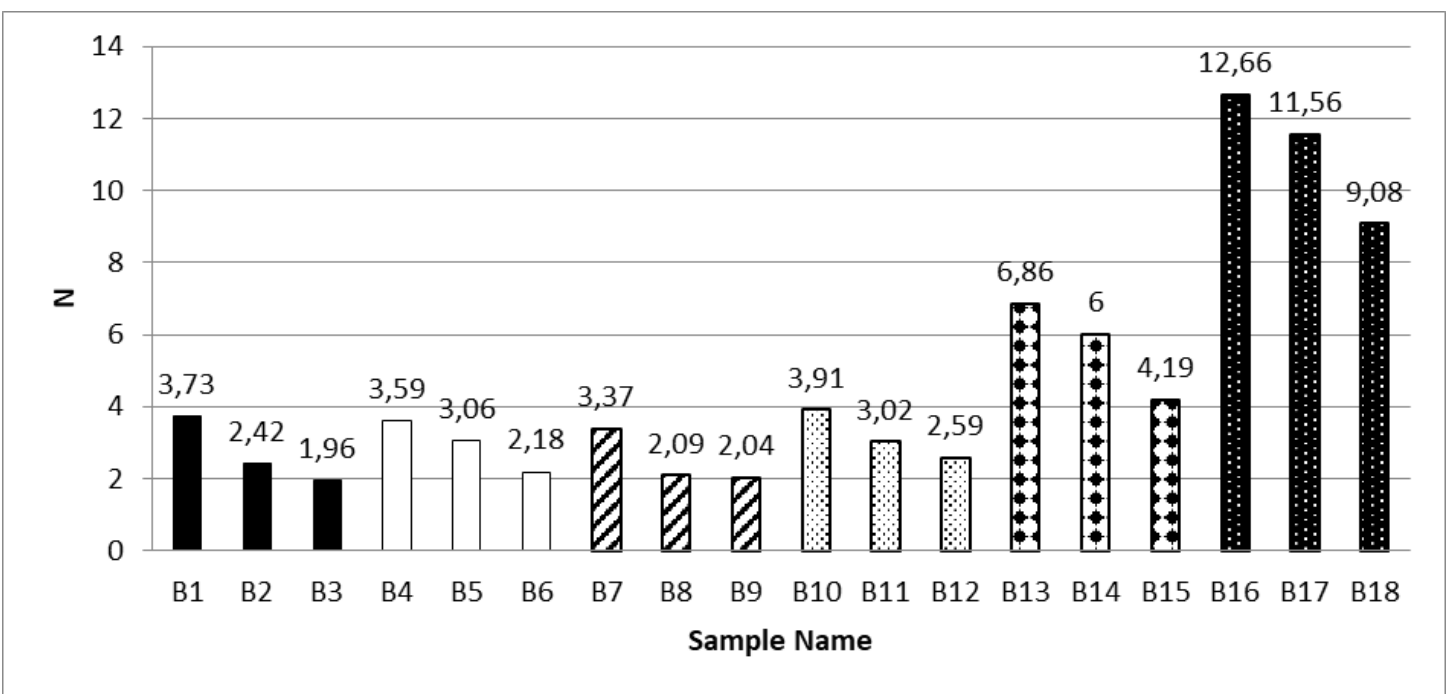

Figure 11. Bending Strength Measurement Results of Group B sample 
Table 8. The Results of Variance Analysis on the Bending Strength of the Needling, Meltblown and Spunbond Surfaces in Group B Samples

\begin{tabular}{|l|l|}
\hline Parameters & Significance \\
\hline Needling wool basis weight &, 000 \\
\hline Needling wool thickness &, 000 \\
\hline Needling viscose basis weight &, 000 \\
\hline Needling viscose thickness &, 000 \\
\hline Meltblown basis weight &, 045 \\
\hline Meltblown thickness &, 045 \\
\hline Spunbond basis weight &, 000 \\
\hline Spunbond thickness &, 000 \\
\hline
\end{tabular}

The measurement results of group C combinations are given in figure 12 .

In the obtained $\mathrm{C}$ group samples, the meltblown surface used in the last layer was softer than spunbond surface and the bending strength results were lower than the B group combinations. The graph shows a decrease in bending strength values as the basis weight and thickness of the meltblown surface decreases in each triple group expressed in different patterns. However, in the C13, C14 and C15 group, are expected to be highest in sample $\mathrm{C} 13$, middle value in sample $\mathrm{C} 14$ and lowest value in sample $\mathrm{C} 15$, the lowest value was given by sample number C14. It is thought that this is due to a lack of homogeneity in the needling layer. According to the results evaluated by variance analysis using SPSS software in C group combinations, the thickness and basis weight values of the meltblown surfaces were not statistically significant, while the thickness and weight values of the needling viscose and wool surfaces were found to be significant according to the $\alpha=0.05$ significance coefficient.

The results are given table 9 .

When the subgroups were examined, as the basis weight of the needling wool and viscose surface increased, the bending strength values increased. The effect of total thickness and weight values on the bending strength of the A, B and C group samples were evaluated statistically using SPSS software, basis weight and thickness values were found to be statistically significant. The values obtained can be seen in table 10 .

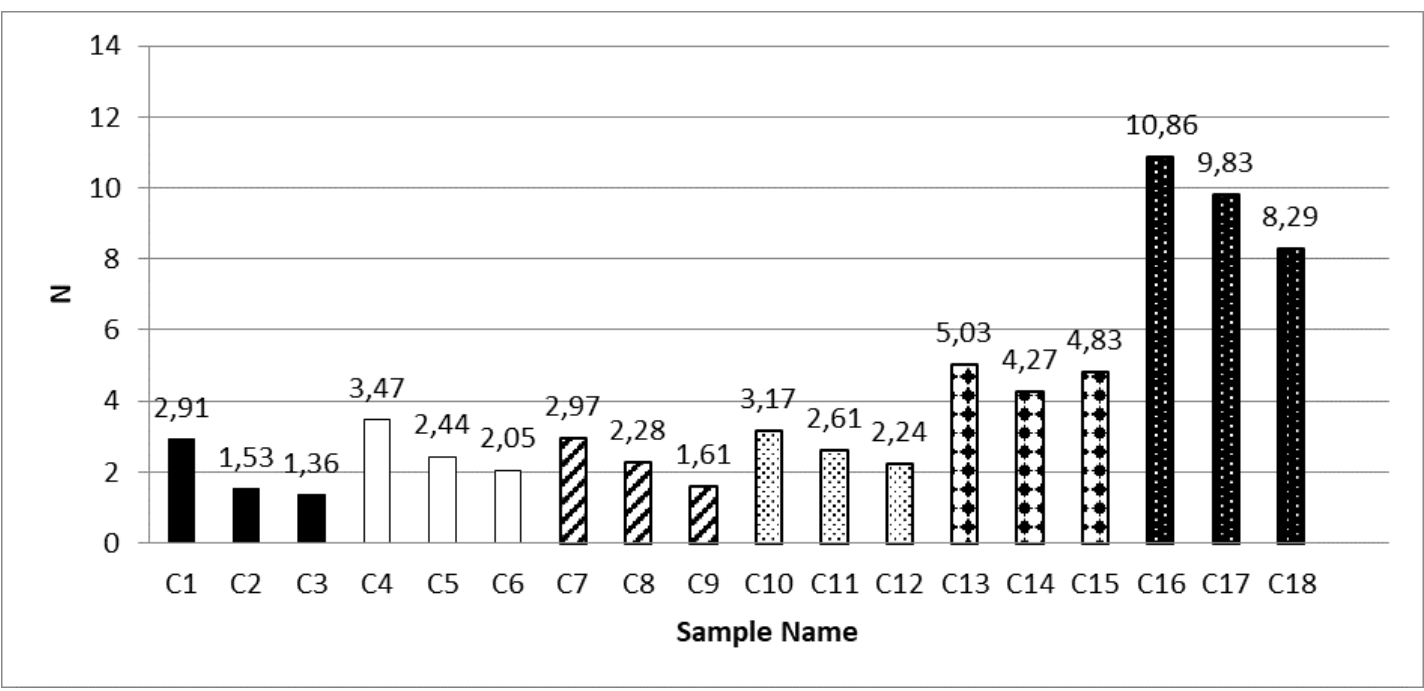

Figure 12. Bending Strength Measurement Results of Group C Sample 
Table 9. The Results of Variance Analysis on the Bending Strength of the Needling and Meltblown Surfaces in Group C Samples

\begin{tabular}{|l|l|}
\hline Parameters & Significance \\
\hline Needling wool basis weight &, 000 \\
\hline Needling wool thickness &, 000 \\
\hline Needling viscose basis weight &, 000 \\
\hline Needling viscose thickness &, 000 \\
\hline Meltblown basis weight &, 169 \\
\hline Meltblown thickness &, 169 \\
\hline
\end{tabular}

Table 10. The Results of Variance Analysis on Bending Strength of Thickness and Basis Weight

\begin{tabular}{|l|l|}
\hline Parameters & Significance \\
\hline Thickness &, 000 \\
\hline Basis weight &, 000 \\
\hline
\end{tabular}

As the total thickness and basis weight increased, the bending strength values increased. Bending strength results can be established between the hardness/softness and formability of the surfaces. It can be said that the softness is highest and the formability is the easiest in the samples where the lowest values are obtained in the measurement results and the hardness is the highest in the samples where the highest values are obtained.

\subsection{Results of Water Vapour Permeability Test}

The water vapor permeability measurement of the samples was measured according to the rotary platform method with SDL Atlas M261 device and BS 7209: 1990 standard.

According to the results of the air permeability, bending strength, thickness and basis weight structure, water vapor permeability test was carried out by selecting samples from group A as the equivalent to the tube knitted stockinette structure, while samples from group B and C were replaced with cotton pad used under cast.

The water vapor permeability values of the selected samples from group A combinations are given in figure 13 .

In the samples selected from the group A combinations to equivalent the structure called stockinette, which combined low weight wool and viscose with 3 different meltblown samples, as the basis weight and thickness of the meltblown surface decreased and the air permeability increased, the water vapor permeability value increased. When wool and viscose are compared, viscose has better water vapor permeability.

Samples A6 and A12 were selected in order to make a comparison according to the weights of needled surfaces, it has been concluded that the increase in the weight of the needle surface has decreased the water vapor permeability value. According to the results, it was observed that these structures give sufficient vapor permeability values which can be used as equivalent to stockinette (especially A8 and A9). It was also observed that samples did not trap moisture on them.

According to the results evaluated by variance analysis using SPSS software in group A combinations, basis weight, thickness and air permeability of meltblown and needling wool and viscose surfaces were not found significant for water vapor permeability according to $\alpha=0.05$ significance coefficient(Table $11)$.

The water vapor permeability values of the selected samples from group B combinations are given in figure 14.

In the samples selected from the group B combinations to equivalent the structure called cotton pad used under cast, which combined low weight wool and viscose with 3 different meltblown samples as the basis weight of the meltblown surface decreased, the water vapor permeability increased. Although the samples numbered B15 and B18 selected to observe the difference created by the spunbond layer were slightly lower, they gave similar results with the two-layered structures and no significant difference was observed. 
According to the results evaluated by variance analysis using SPSS software in B group combinations, the thickness, weight and air permeability of the meltblown and spunbond surfaces and the thickness values of the wool surfaces were not statistically significant while the weight and air permeability values of the needle wool surfaces and the weight, thickness and air permeability of the needle viscose surfaces were found to be significant for water vapor permeability according to the $\alpha=0.05$ significance coefficient.

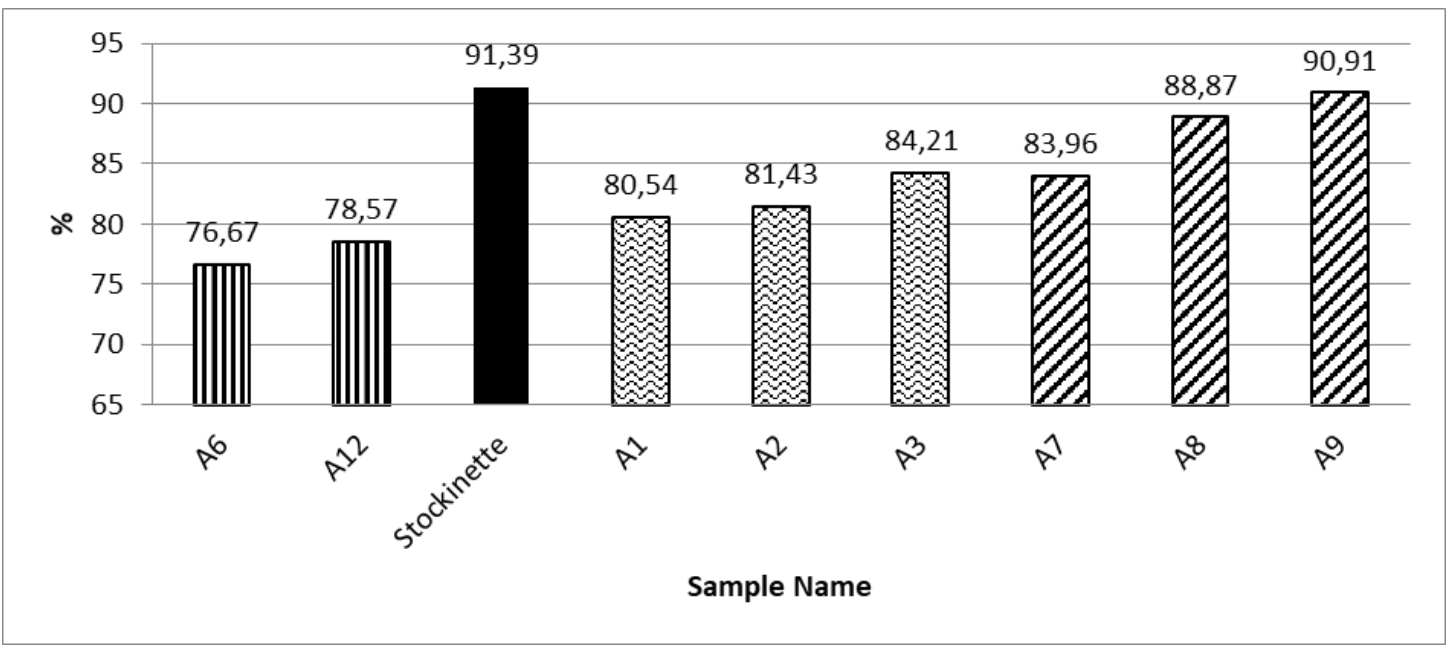

Figure 13. Water Vapor Permeability Measurement Results of Group A Sample

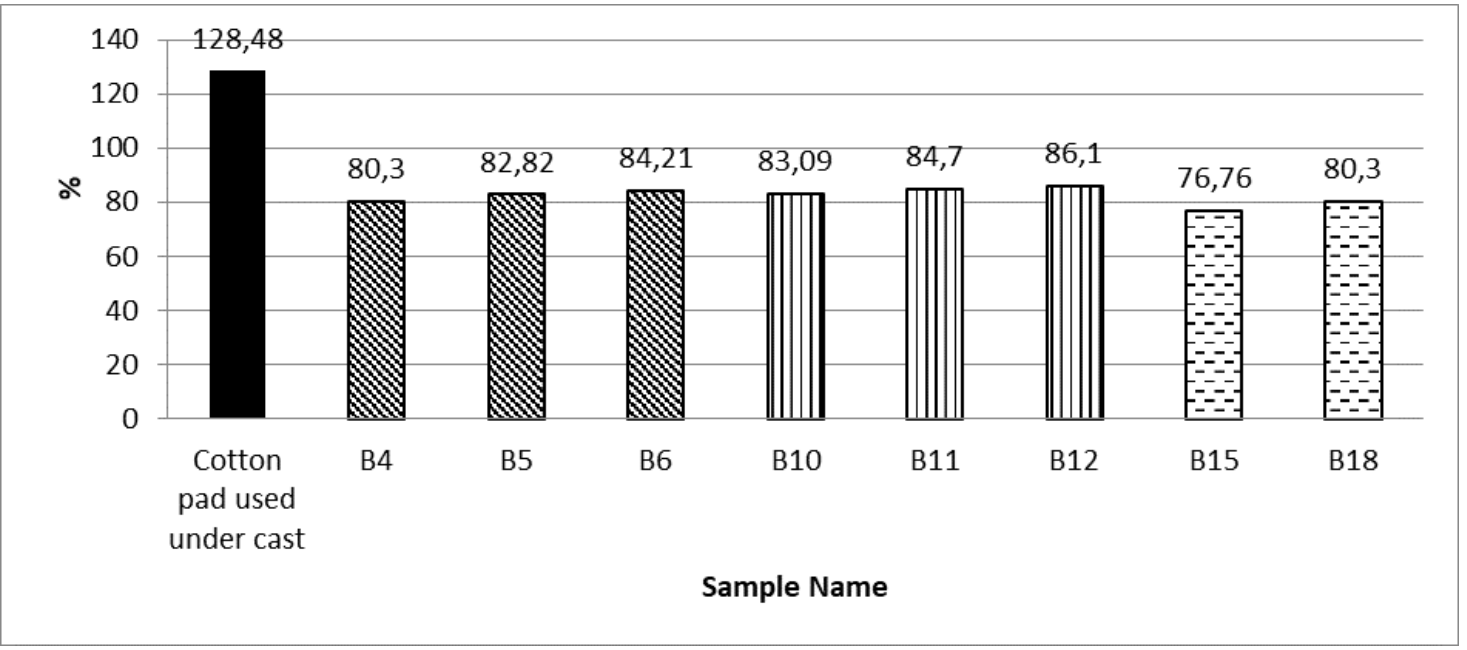

Figure 14. Water Vapor Permeability Measurement Results of Group B Sample

Table 11. The Results of Variance Analysis on the Water Vapor Permeability of the Needling and Meltblown Surfaces in Group A Samples

\begin{tabular}{|l|l|}
\hline Parameters & Significance \\
\hline Needling wool basis weight &, 264 \\
\hline Needling wool thickness &, 264 \\
\hline Needling wool air permeability &, 264 \\
\hline Needling viscose basis weight &, 061 \\
\hline Needling viscose thickness &, 168 \\
\hline Needling viscose air permeability &, 061 \\
\hline Meltblown basis weight &, 845 \\
\hline Meltblown thickness &, 845 \\
\hline Meltblown air permeability &, 845 \\
\hline
\end{tabular}


The results are given table 12 .

Water vapor permeability values of the samples selected from group $\mathrm{C}$ combinations are given in figure 15. Samples with the same structure were selected in order to observe the difference between the use of spunbond surface and meltblown surface.

The water vapor permeability values of the selected samples from group $\mathrm{C}$ combinations are given in figure 15.

Table 12. The Results of Variance Analysis on the Water Vapor Permeability of the Needling, Meltblown and Spunbond Surfaces in Group B Samples

\begin{tabular}{|l|c|}
\hline Parameters & Significance \\
\hline Needling wool basis weight &, 047 \\
\hline Needling wool thickness &, 060 \\
\hline Needling wool air permeability &, 047 \\
\hline Needling viscose basis weight &, 047 \\
\hline Needling viscose thickness &, 047 \\
\hline Needling viscose air permeability &, 047 \\
\hline Meltblown basis weight &, 786 \\
\hline Meltblown thickness &, 786 \\
\hline Meltblown air permeability &, 786 \\
\hline Spunbond basis weight &, 524 \\
\hline Spunbond thickness &, 524 \\
\hline Spunbond air permeability &, 524 \\
\hline
\end{tabular}

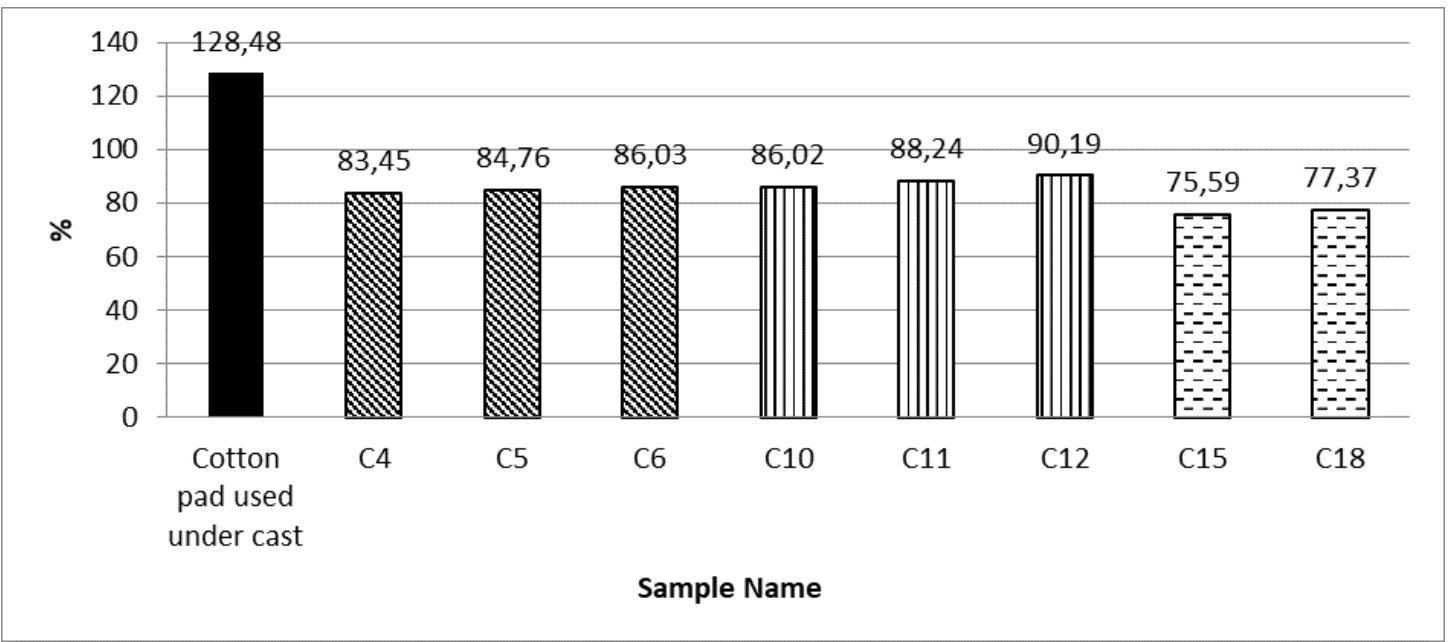

Figure 15. Water Vapor Permeability Measurement Results of Group C Sample

Water vapor permeability value increased as the meltblown surface basis weight decreased in samples which high-weight wool and high-weight viscose combined with 3 different meltblowns selected from the group $\mathrm{C}$ combinations which were equivalent to cotton pad used under the cast.

When compared with the B group samples, the samples using the meltblown surface in the under layer gave a higher water vapor permeability value. Samples C15 and C18 were selected to observe the difference of structures with more layers. It has been observed that these samples with thicker and higher weight give low results.

According to the results evaluated by one-way variance analysis using SPSS software in C group 
combinations, the thickness, weight and air permeability values of meltblown surfaces were not significant, while the weight, thickness and air permeability values of the needling wool and viscose surfaces were significant according to the $\alpha=0.05$ signifiance coefficient.

The results are given table 13 .

Table 13. The Results of Variance Analysis on the Water Vapor Permeability of the Needling and Meltblown Surfaces in Group C Samples

\begin{tabular}{|l|l|}
\hline Parameters & Significance \\
\hline Needling wool basis weight &, 002 \\
\hline Needling wool thickness &, 010 \\
\hline Needling wool air permeability &, 002 \\
\hline Needling viscose basis weight &, 002 \\
\hline Needling viscose thickness &, 002 \\
\hline Needling viscose air permeability &, 002 \\
\hline Meltblown basis weight &, 686 \\
\hline Meltblown thickness &, 686 \\
\hline Meltblown air permeability &, 686 \\
\hline
\end{tabular}

When the results obtained from the B and $\mathrm{C}$ group combinations were compared with the cotton pad used under cast, it was observed that the values were lower, however, as a result of the measurements, it was observed that the cotton pad used under cast trapped the water vapor in the structure and not dried up easily. Dry weight obtained at the beginning of the experiment at the end of the experiment tripled by 3 times the structure has occurred. This will lead to a feeling of discomfort when the user is wet with perspiration in terms of comfort. However, this situation has not been observed in samples produced as equivalent to it.

\section{Conclusion}

In this study, two-, three-, and multi-layered nonwoven structures have been developed in order to provide comfort in patients with long lasting fracture treatments under cast and orthopedic bandages. Group A samples from these structures combined with three different combinations are used as the equivalent to the structure called tube-knitted stockinette which is used under American plaster cast today, while B and C group samples are used as synthetic or synthetic/natural fiber called cotton pad used under cast. It is produced as a equivalent to non-fixing fiber. The reason for using meltblown structure is to allow breathing with microlifers, to provide softness and not to damage the skin, while the spunbond structure is used to facilitate the application of plaster and to give a smooth form to the structure.

In all three groups, 18 different samples were produced and air permeability, thickness, bending strength, basis weight and water vapor permeability tests were performed. When the samples are examined, it is clearly seen that the surface that formed the difference in thickness results is the surface created by needling method. Samples with low-weight wool and viscose needling surfaces had lower results than samples with high-weight wool and viscose needling surfaces. As the number of surfaces used increased, an increase in thickness results was observed.

When the basis weight measurement results are examined, while the combination of low weight wool and viscose were obtained the lowest result; combination of high weight wool and viscose were obtained higher results. The highest results were obtained in the samples where the most layers were combined. When the air permeability measurement results of the A group samples are examined; air permeability measurements of combinations with meltblown M1 surface gave the lowest values. This is due to the fact that the surface area of M1 is $95 \mathrm{~g} / \mathrm{m} 2$ and has the highest thickness, the most heavy and volumnious meltblown surface, and the air permeability of the M1 surface alone is lower than the M2 and M3 surfaces. In combination with the M2 and M3 surfaces, values increase in order. The combinations with $54 \mathrm{~g} / \mathrm{m} 2$ weighted M2 surface gave higher values, and combinations with $38 \mathrm{~g} / \mathrm{m} 2$ weighted M3 surface gave the highest values.

When the effect of the needling surface on air permeability was examined, it was observed that the 
combinations made with low-weight surfaces (N V1 and N W1) had higher air permeability than the combinations made with high-weight surfaces (N V2 and N W2 ). This was observed for all three meltblown groups (M1, M2 and M3) in the same manner.

When the air permeability results of the B group samples were examined, it was observed that the weight of the meltblown surface and the needling surface, as in group A combination, affected the air permeability. It was also found to be lower than the A group samples. This difference is due to the spunbond surface, the third layer being used.

Differences were observed in the $\mathrm{C}$ group combination due to the meltblown surface and the needling surface. The measurement results of these samples were lower than the B group samples. This difference is due to the fact that the meltblown surface used as the final layer has a more closed (less porous) structure than the spunbond surface.

When the bending strength results of the A group samples were examined, it was observed that the bending strength values of the combinations with low weight wool (N W1) and low weight viscose (N V1 ) were the lowest, while the values of the samples increased with increasing thickness and thickness of the samples. When the results of bending strength of B group samples are examined; higher results were obtained than the A group results. This is because the spunbond surface is used as an additional layer. In the $\mathrm{C}$ group samples, the meltblown surface used in the last layer was softer than the spunbond surface used and the bending strength results were lower than the B group combinations. Bending strength results can be established between the hardness/softness and formability of the surfaces. It can be said that the softness is highest and the formability is the easiest in the samples where the lowest values are obtained in the measurement results whereas the hardness is the highest in the samples where the highest values are obtained.

The water vapor permeability test was investigated as an indicator of the excretion of moisture due to sweating. In the samples where the low-weight wool and low-weight viscose, which were selected as equivalent to the stockinette structure, were combined with 3 different meltblown samples, the water vapor permeability value increased as the weight of the meltblown surface decreased. When wool and viscose are compared, it is observed that viscose has better water vapor permeability. B and C group combinations, in combination with 3 different meltblown high weight wool and high weight viscose, are selected as equivalent to the cotton pad used under cast as the meltblown surface weight decreased, the water vapor permeability value increased. Samples using meltblown surface in the under layer gave higher water vapor permeability value. This is believed to be due to the softer meltblown structure and therefore the cause for better penetration of the needles during the surface bonding, with better penetration of the layers between the layers. In addition, as a result of the measurements, it was observed that the cotton pad used under cast trapped the water vapor in its structure. In the structure from the beginning weight of the experiment to the end weight of the experiment has occurred tripled weight increase. This will lead to a feeling of discomfort when the user is wet with perspiration in terms of comfort. However, this situation has not been observed in samples produced as equivalent to it.

As a result of this study, during the long-term demanding healing process; it is expected to provide better physiological comfort, more comfortable treatment process for patients, and ease of application for health personnel.

\section{References}

Rigby, A.J., Anand, S.C. (2003) Medical textiles, Handbook of Technical Textiles, A. R., Horrocks and S. C. Anand (Eds.), Cambridge

Sönmez (2007) M. Sönmez, M.Sc. Dissertation, EU, Izmır,

Domanski et al. (2003) U. S. Patent, 6582382 A

Evans (2008) J. C. Evans, Patent, WO 2008042839 A3

Kim, Youn and Choi (2010) Patent, WO 2010131840 A2 (2010)

Evans (2012) U. S. Patent, 20120220908 A1

Duran, K., (2004) Dokusuz Yüzeyler, Izmır, 2004. () 